\title{
Pengaruh Penggunaan Media Daring dan Motivasi Belajar Terhadap Kepuasan Mahasiswa Pada Saat Pandemi Covid-19
}

\author{
Mujibul Hakim', Aria Mulyapradana² \\ ${ }^{1}$ ITS NU Pekalongan \\ e-mail: mujibulhakim@gmail.com \\ ${ }^{2}$ Politeknik Pusmanu \\ e-mail: ariamulyapradana@gmail.com
}

\begin{abstract}
Abstrak - Tujuan dari riset ini untuk mengetahui adanya pengaruh media daring dan motivasi belajar terhadap kepuasan mahasiswa pada masa pandemi Covid-19 di Kampus ITS NU Pekalongan dan Politeknik Pusmanu. Adanya peristiwa pandemi ini berdampak ke semua sektor salah satunya adalah pendidikan, sebelum pandemi terjadi tatap muka menjadi media dalam interaksi belajar akan tetapi saat ini beralih ke sistem dalam jaringan (daring), kegiatan daring ini berlaku seluruh tingkat pendidikan. Adapun media pembelajaran dalam jaringan sudah diterapkan sejak awal pandemi menjadi alternatif dalam menyampaikan materi belajar. Dari berbagai jenis media pembelajaran yang dilakukan selama pandemi ini google classroom menjadi pilihan utama yang dipilih oleh responden. Hasil riset menunjukan bahwa variabel penggunaan media daring dan motivasi belajar memiliki nilai positif berarti semakin baik pilihan dalam penggunaan media daring dan motivasi maka mahasiswa akan merasa puas. Hasil persamaan regresi dalam riset ini adalah $\mathrm{Y} 1=0,543 \mathrm{X}_{1}+0,189 \mathrm{X}_{2}$ dengan nilai Adjusted $R$ Square sebesar 0,448. Objek riset ini adalah 125 mahasiswa dari Program Studi Teknologi Informatika ITS NU Pekalongan dan Program Studi Administrasi Perkantoran Politeknik Pusmanu adapun metode riset ini adalah kuantitaif deskriptif yang menggunakan SPSS versi 19.0 dengan metode analisa data antara lain uji validitas, uji reliabilitas, analisis regresi linier berganda dan menggunakan uji t. Kesimpulan dari riset ini menyatakan bahwa menunjukan penggunaan media daring mempunyai pengaruh terhadap kepuasan mahasiswa dan motivasi belajar tidak terlalu berpengaruh terhadap kepuasan mahasiswa.
\end{abstract}

\section{Kata kunci : Covid-19, Daring, Kepuasan, Mahasiswa, Motivasi Belajar}

Abstract - The purpose of this research is to determine the influence of online media and learning motivation on student satisfaction during the Covid-19 pandemic at ITS NU Pekalongan and Polytechnic Pusmanu. The existence of this pandemic event has an impact on all sectors, one of which is education, before the pandemic occurred faceto-face became a medium for learning interactions, but currently switching to online systems, this online activity applies to all levels of education. As for online learning media, it has been implemented since the beginning of the pandemic as an alternative in delivering learning material. Of the various types of learning media carried out during this pandemic, google classroom is the main choice chosen by respondents. The research results show that the variables of online media use and learning motivation have a positive value, meaning that the better the choice of online media use and motivation, the students will feel satisfied. The result of the regression equation in this research is $Y 1=0.543 X 1+0.189 X 2$ with an Adjusted $R$ Square value of 0.448. The objects of this research were 125 students from ITS NU Pekalongan Informatics Technology Study Program and Polytechnic Pusmanu Office Administration Study Program. This research method is descriptive quantitative using SPSS version 19.0 with data analysis methods including validity testing, reliability testing, multiple linear regression analysis and using the $t$ test. The conclusion of this research states that it shows that online media use has an effect on student satisfaction and learning motivation does not significantly affect student satisfaction.

Keywords: Covid-19, Online, Satisfaction, Students, Learning Motivation

\section{PENDAHULUAN}

Faktor utama kemajuan suatu bangsa salah satunya dilihat dari sistem pendidikan di suatu negara, untuk mendapatkan kualitas unggul maka perlunya sistem pendidikan yang baik di Indonesia. Dunia pendidikan memiliki peranan penting dalam kehidupan diantaranya adalah menyiapkan tenaga kerja yang profesional dan menghasilkan tenaga ahli yang unggul serta terpenuhinya kebutuhan Sumber Daya Manusia untuk mengisi posisi atau jabatan di indutri maupun di pemerintahan. Sumber Daya Manusia yang unggul secara tidak langsung akan membantu dalam meningkatkan kualitas kehidupan manusia seperti perkembangan teknologi informatika yang mengalami perkembangan dari masa ke masa 
dapat membantu manusia dalam kehidupan sehariharinya sebagai contoh di era digital ini semua informasi yang dibutuhkan manusia dapat tersampaikan dengan cepat dan mudah didapat hal tersebut dikarena kemudahaan dalam mengakses internet sehingga manusia dengan leluasa mendapatkan beragam informasi yang dibutuhkan dengan cepat. Inter-networking atau yang disebut dengan internet merupakan jaringan yang terdiri kumpulan perangkat komputer yang terhubung dengan protokol yakni TCP/IP (transmission control protocol/internet protocol) tertentu guna mendapatkan pertukaran informasi antar komputer sehingga internet menyediakan segala informasi untuk pemakainya yang tersebar di seluruh dunia (Setiyani, 2010).

Seperti halnya di awal tahun 2020 ini semua masyarakat di seluruh dunia memperoleh informasi terkait pandemi Covid-19 melalui internet. Informasi mengenai pandemi Covid-19 dari berbagai penyedia infomasi/berita menyita perhatian masyarakat dunia, dari informasi tersebut banyak negara mulai mengeluarkan kebijakan guna mengantisipasi wabah tersebut. Perkembangan pandemi Covid-19 di bulan Maret 2020 yang semakin meningkat, mengakibatkan terhambatnya semua aktivitas masyarakat di seluruh dunia yang berdampak terhadap perekonomian yang melemah. Tidak hanya sektor ekonomi saja melainkan seluruh sektor mengalami dampak akibat pandemi ini.

Di Indonesia, dampak pandemi ini memiliki dampak yang besar bagi seluruh sektor salah satunya adalah sektor pendidikan dimana sebelum adanya pandemi ini aktivitas kegiatan belajar mengajar dilakukan secara tatap muka. Melihat kondisi tersebut maka proses belajar mengajar harus tetap dijalankan, oleh karena itu pengalihan media pembelajaran guna keberlangsungan proses belajar mengajar dimana yang semula dilakukan tatap muka beralih melalui media dalam jaringan (daring). Kegiatan belajar mengajar yang dilakukan secara dalam jaringan (daring) berlaku untuk semua tingkat pendidikan. Maka, peran internet dalam dunia pendidikan pada masa pandemi ini sangat membantu dan mengalami peningkatan dari segi penggunaannya.

Sesuai dengan edaran dari Kemendikbud RI Nomor 3 Tahun 2020 tentang Pencegahan Corona Virus Disease (COVID-19) pada Satuan Pendidikan dan Surat Sekjen Mendikbud nomor 35492/A.A5/HK/2020 tanggal 12 Maret 2020 perihal Pencegahan Penyebaran Corona Virus Disease (Covid-19) serta mengikuti juga edaran dan himbauan dari masaing-masing Pemerintah Daerah domisili Perguruan Tinggi (Suni Astini, 2020).

Berdasarkan keputusan tersebut maka proses belajar mengajar diwajibkan untuk melakukan kegiatan tersebut dari rumah atau yang disebut dengan stay at home yang dilaksanakan serentak pada bulan Maret 2020. Melihat kondisi tersebut maka beberapa penyelenggara pendidikan sudah memulai atau beralih dari metode tatap muka menjadi metode pembelajaran dalam jaringan (daring) dalam proses belajar mengajar, akan tetapi dalam pelaksanaanya banyak dari mereka yakni pendidik dan peserta didik masih awam atau menjadi hal yang baru dalam teknis menyelenggarakan proses belajar mengajar di masa pandemi ini.

Secara tidak langsung mereka telah menerapkan proses belajar yang menggunakaan media online, hal ini dapat terlihat hampir sebagian besar dari mereka adalah pengguna smartphone dan aplikasi media sosial contohnya mereka belajar komunikasi dengan orang lain menggunakan sosial media seperti whatshapp hanya saja mereka tidak menyadari bahwa kegiatan tersebut merupakan bagian dari proses pembelajaran.

Dengan adanya pandemi Covid-19 ini, mendorong banyak profesional di dunia pendidikan harus berpikir kreatif dalam kegiatan belajar mengajar seperti penguasaan teknologi untuk media belajar secara dalam jaringan (daring) contoh media pembelajaran antar lain whatsapp, google classroom dan aplikasi zoom. Perubahan media pembelajaran menjadi tantangan di dunia pendidikan dikarenakan mereka tidak mengetahui dan menggunakan aplikasi tersebut sebelum masa pandemi terjadi.

Hal ini berdampak pada mahasiswa dimana mereka harus mengalihkan metode pembelajarannya dengan menggunakan aplikasi pendukung perkuliahan online (daring). Media pembelajaran merupakan perantara komunikasi yang terdiri dari guru (komunikator), siswa (komunikan), bahan ajar, media pembelajaran dan tujuan pembelajaran. Guru sebagai komunikator memiliki tugas untuk membimbing dan mengarahkan siswa dalam belajar agar memperoleh pemahaman dan hasil yang maksimal dari kegiatan belajar mengajar menggunakan media pembelajaran (Romadon \& Maryam, 2019). Media pembelajaran dalam riset ini yakni aplikasi media belajar seperti Zoom, Google Classroom, Google Meeting dan Whatsapp.

E-learning merupakan bagian dari media pembelajaran dalam proses belajar mengajar di masa pandemi ini. Adapun mempunyai ciri-cirinya, antara lain (Hanum, 2013); 1) tujuan pembelajaran yang relevan dengan konten; 2) penggunaan metode instruksional dalam pembelajaran; 3) penggunaan elemen-elemen media dalam penyampaian materi belajar; 4) pembelajaran secara terpusat pada pengajar atau dirancang untuk pembelajaran secara mandiri; 5) menciptakan pemahaman dan keterampilan terkait dengan tujuan pembelajaran.

Dampak yang dirasakan secara langsung oleh mahasiswa adalah metode pembelajaran yang menggunakan jaringan internet dapat mengakibatkan biaya pengeluaran pulsa internet meningkat dari sebelumnya, sulitnya berinteraksi kepada dosen ketika mereka dihadapkan dengan meteri yang belum mereka pahami dan selama masa pembelajaran dalam jaringan (daring) terjadi komunikasi satu arah. Hal 
yang sama dirasakan oleh pendidik dalam hal ini adalah dosen, mereka tidak megetahui secara langsung tingkat pemahaman peserta didik pada saat penyampaian materi. Hal ini didukung oleh hasil riset yang dilakukan oleh Mursyid (Naserly, 2020) yang berjudul Implementasi Zoom, Google Classroom, dan Whatsapp Group Dalam Mendukung Pembelajaran Daring (Online) Pada Mata Kuliah Bahasa Inggris Lanjut mengatakan bahwa penggunaan aplikasi zoom menguras kuota internet, pemahaman materi yang rendah dengan aplikasi google classroom dan respon komunikasi yang lamban dengan whatsapp.

Tantangan terbesar agar motivasi belajar mahasiswa di masa pandemi ini tetap terjaga dengan baik maka peran dosen dan mahasiswa sangat berpengaruh terhadap motivasi tersebut. Motivasi yang berasal dari kata motif memiliki arti daya dorong, keinginan, kebutuhan dan kemauan (Romadon \& Maryam, 2019). Motivasi merupakan dorongan yang dimiliki seseorang sehingga dapat menimbulkan, mengarahkan dan mengorganisasi tingkah laku (Setiawan \& Mulyapradana, 2018). Motivasi merupakan bagian proses psikologi yang dimiliki oleh seseorang yang menggambarkan suatu interaksi antara sikap, persepsi, kebutuhan dan keputusan (Mujibul \& Hakim, 2019). Ada tiga karakteristik dalam motivasi (Setiawan \& Mulyapradana, 2018) antara lain: usaha, kemauan keras dan arah atau tujuan.

Dalam riset ini motiviasi yang dikaji adalah motivasi belajar mahasiswa dimana dorongan atau kemampuan yang dimiliki seseorang mahasiswa dalam melakukan aktivitas belajarnya agar prestasi belajarnya dapat dicapai secara optimal. Ciri-ciri dari motivasi belajar yang tinggi antara lain : bekerja keras, tangguh, pantang menyerah, memiliki tujuan untuk masa depan, mempunyai semangat untuk menyelesaikan pekerjaan dengan tingkat kesukaran yang sedang dan mampu menyelesaikan permasalahan yang dihadapi (Mulyaningsih, 2014). Hal senada yang diutarakan oleh Arko Pujadi bahwa faktor-faktor yang mempengaruhi motivasi belajar mahasiswa yakni faktor yang ada didalam diri sendiri (intrinsik) dan faktor yang berada di luar diri sendiri (Pujadi, 2007). Riset yang dilakukan oleh I Made Ari (Winangun, 2020) motivasi belajar terdapat dua dimensi yakni dimensi intrinsik yang terdiri dari adanya hasrat dan keinginan berhasil, adanya dorongan dan kebutuhan dalam belajar, serta adanya harapan dan cita-cita masa depan dan dimensi ekstrinsik yang terdiri dari adanya penghargaan dalam belajar, adanya kegiatan yang menarik dalam belajar dan adanya lingkungan belajar yang kondusif.

Melihat fenomena tersebut sebagian besar mahasiswa masih termotivasi untuk melaksanakan proses pembelajaran meskipun ada beberapa dari mahasiswa yang motivasinya menurun. Hal ini diperkuat dari hasil riset yang dilakukan oleh Yani, Irfan dan Mia (Fitriyani et al., 2020) yang berjudul
Motivasi Belajar Mahasiswa Pada Pembelajaran Daring Selama Pandemik Covid-19 mengatakan bahwa ditengah pandemi Covid-19 yang melanda dunia tidak menjadi alasan mahasiswa untuk tetap termotivasi dalam belajar meski pelaksanaanya terdapat beberapa kendala.

Objek riset ini adalah kampus ITS NU Pekalongan dan Politeknik Pusmanu yang berada di wilayah Pekalongan pada semester genap tahun ajaran 2019/2020 telah melaksanakan pembelajaran kuliah oline (daring). Berdasarkan hasil evaluasi belajar mahasiswa di semester ini menunjukan adanya penurunan prestasi akademik. Hal tersebut menjadi salah satu faktor ketidakpuasan mahasiswa dalam proses pembelajaran secara online dibuktikan dengan rata-rata IPK yang didapatkan oleh mahasiswa dari semester sebelumya dengan semester ini masih kurang memuaskan hal ini berdampak terhadap kinerja pembelajaran yang kurang maksimal.

Kotler dan Keller (Mulyapradana et al., 2020) kepuasan adalah perasaan senang atau kecewa seseorang yang timbul karena membandingkan kinerja yang dipersepsikan produk (atau hasil) terhadap ekspetasi mereka. Hal senada yang diungkapkan oleh M.N Nasution (Mulyapradana, 2017) mengatakan "bahwa kepuasan merupakan tingkat perasaan seseorang setelah membandingkan kinerja atau hasil yang ia rasakan dibandingkan dengan harapannya". Ada tiga indikator dalam mengukur kepuasan antara lain (Mulyapradana et al., 2020) : adanya kesesuaian kualitas pelayanan dengan tingkat harapan, tingkat kepuasan apabila dibandingkan dengan yang sejenis dan tidak ada pengaduan atau komplain yang dilayangkan.

Dari fenomena tersebut maka peneliti tertarik untuk meneliti dengan judul pengaruh penggunaan media daring dan motivasi belajar terhadap kepuasan mahasiswa pada saat pandemi Covid-19. Adapun tujuan dari riset ini adalah untuk mengetahui adanya pengaruh media daring, motivasi belajar terhadap kepuasan mahasiswa pada saat pandemi Covid-19 di Kampus ITS NU Pekalongan dan Politeknik Pusmanu.

\section{METODE PENELITIAN}

Jumlah responden dalam riset ini sebanyak 125 responden yang terdiri dari mahasiswa Program Studi Teknologi Informasi ITS NU Pekalongan dan mahasiswa Program Studi Administrasi Perkantoran Politeknik Pusmanu. Riset ini menggunakan metode kuantiatif deskriptif dengan menggunakan SPSS versi 19.0. Metode analisa data di riset ini adalah dengan menggunakan uji validitas, uji reliabilitas, analisis regresi linier berganda dan menggunakan uji $\mathrm{t}$ untuk mengetahui pengaruh dari masing-masing variabel. 


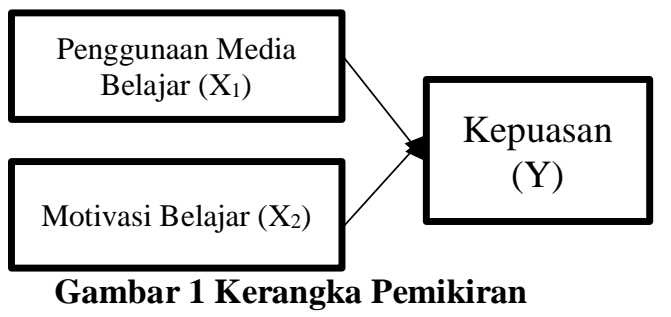

H1: Adanya pengaruh penggunaan media daring terhadap kepuasan

$\mathrm{H} 2$ : Adanya pengaruh motivasi belajar terhadap kepuasan

\section{HASIL DAN PEMBAHASAN}

Responden riset ini dilakukan di kampus ITS NU Pekalongan Program Studi Teknologi Informasi dan Politeknik Pusmanu Program Studi Administrasi Perkantoran berjumlah 125 responden dan data riset yang diperoleh dilakukan dengan cara penyebaran kuesioner melalui google form.

Dari penyebaran kuesioner tersebut diperoleh hasil deskripsi responden sebagai berikut: terdapat 3 kategori golongan usia dalam responden di riset ini yakni golongan usia 17-22 tahun, 23-28 tahun dan 2934 tahun. Penyebaran responden tersebut antara lain sebanyak 116 responden $(92,8 \%)$ yang berusia $17-22$ tahun, sebanyak 6 responden $(4,8 \%)$ yang berusia 23 28 tahun dan yang terakhir sebanyak 3 responden $(2,4 \%)$ yang berusia 29-34 tahun. Hal ini dapat terlihat bahwa mayoritas usia responden dalam riset ini berusia antara 17 tahun hingga 22 tahun.

Sedangkan responden berdasarkan jenis kelamin sebanyak 54 responden $(43,2 \%)$ adalah laki-laki dan sisanya yang berjumlah 71 responden $(56,8 \%)$ adalah perempuan. Dan data responden berdasarkan institusi perguruan tinggi yakni responden yang kuliah di Politeknik Pusmanu sebanyak 69 responden $(55,2 \%)$ dan ITS NU Pekalongan sebanyak 56 responden $(44,8 \%)$.

Dalam riset ini peneliti melakukan observasi awal mengenai media pembelajaran yang sering digunakan oleh mahasiswa dalam kuliah online dari data yang diperoleh bahwa media pembelajaran melalui google classroom menjadi pilihan utama dalam kuliah online dapat terlihat bahwa dari 125 responden ini sebanyak 58 responden (46,4\%) yang memilih google classroom sebagai media kuliah online yang dipilih. Selanjutnya sebanyak 52 responden $(41,6 \%)$ mahasiswa memilih menggunakan media whatsapp group dalam kuliah online dan media Zoom sebanyak 9 responden $(7,2 \%)$ serta yang terakhir adalah media google meeting diperoleh sebanyak 6 responden $(4,8 \%)$. Dari data tersebut diperoleh mahasiswa memiliki antusias untuk kuliah online dengan menggunakan media google classroom dan whatsapp. Berdasarkan hasil wawancara yang dilakukan peneliti kepada beberapa responden dalam riset ini mengatakan bahwa media google classroom memiliki fiture yang menarik seperti ada pengiriman materi pembelajaran yang dilakukan oleh dosen pengampu yang dapat diakses oleh mahasiswa dengan mudah, mahasiswa dapat membuka materi yang dikirim oleh dosen di waktu kapan pun dan mudah dalam penggunanya terutama pada saat penyampaian materi serta media ini menyediakan fiture tugas atau lembar kerja dimana mahasiswa dapat secara langsung melihat nilai yang diberikan oleh dosen pengampu terhadap tugas yang diberikan. Disamping itu, google classroom terdapat fiture komunikasi atau (chat room) yang dapat digunakan oleh dosen maupun mahasiswa untuk berkomunikasi.

Media pembelajaran selanjutnya yakni whatsapp group, media ini menjadi pilihan responden dalam memilih media pembelajaran karena untuk media pembelajaran ini biaya untuk kuota jaringan tidak terlalu banyak yang harus dikeluarkan oleh mahasiswa karena hampir sebagian besar provaider komunikiasi memberikan paket gratis dalam penggunaan whatsapp sehingga ini menjadi alasan mahasiswa tertarik untuk menggunakan whatsapp group sebagai media pembelajaran.

Sedangkan untuk media lainnya berdasarkan hasil wawancara dikatakan bahwa media pembelajaran tersebut sangat menguras biaya kuota dalam kegiatan kuliah online karena media tersebut memiliki fiture hanya sebagai telekonferensi atau pertemuan berbasis elektronik secara langsung yang melibatkan dua atau lebih partisipan.

Selanjutnya untuk mengetahui hipotesa dari riset ini maka penulis melakukan uji validitas, uji reliabilitas, uji Analisa regresi berganda dan uji t. Berikut diperolehan hasil data melalui penyebaran kuesioner;

\section{Uji Validitas}

Untuk uji validitas dalam riset ini menggunkan analis faktor, terlebih dahulu peneliti melakukan uji KMO untuk mengetahui valid atau tidaknya suatu item dalam kuesioner yang disebar agar dapat mengetahui nilai loading factor. Jika nilai loading factor $>0,4$ maka dikatakan valid. Untuk variabel di riset ini dipeorleh nilai KMO nya sebagai berikut: Penggunaan Media Daring $\left(\mathrm{X}_{1}\right)$ sebesar 0,695, motivasi belajar $\left(\mathrm{X}_{2}\right)$ sebesar 0,745 dan kepuasan $(\mathrm{Y})$ sebesar 0,652. Berdasarkan tabel 1 menunjukan bahwa variabel penggunaan media daring, motivasi belajar dan kepuasan memiliki KMO lebih besar dari 0,5 hal ini menunjukan bahwa kriteria kecukupan sampel dari riset ini telah terpenuhi. Sementara untuk indikator-indikator dalam riset ini menunjukan nilai loading factor > 0,4 menunjukan bahwa semua indikator dinyatakan valid.

Dalam riset ini $86,9 \%$ mahasiswa sudah paham dengan intruksi pembelajaran daring disetiap pertemuan kuliah, 85,6\% mahasiswa masih termotivasi untuk selalu mengerjakan tugas yang 
diberikan oleh dosen selama kuliah daring. Akan tetapi hanya $49,1 \%$ mahasiswa yang memperhatikan jika dosen sedang menyampaikan materi kuliah secara daring sisanya $55,1 \%$ mahasiswa tidak memperhatikan, $82,5 \%$ mahasiswa merasa puas jika proses pembelajaran tidak ada kendala jaringan internet. Faktor yang membuat mahasiswa merasa tidak puas adalah hampir sebagian besar dari mereka mengalami kendala jaringan dan kuota internet untuk mengikuti kuliah daring dengan $44,9 \%$ tingkat kepuasan.

Table 1 Uji Validitas

\begin{tabular}{|c|c|c|c|c|}
\hline Variabel & KMO & Item & $\begin{array}{l}\text { Loading } \\
\text { Factor } \\
\end{array}$ & Keterangan \\
\hline \multirow[t]{5}{*}{ Penggunaan Media Daring $\left(\mathrm{X}_{1}\right)$} & \multirow[t]{5}{*}{0,695} & $\mathrm{X} 1.1$ & 0,828 & Valid \\
\hline & & $\mathrm{X} 1.2$ & 0,766 & Valid \\
\hline & & $\mathrm{X} 1.3$ & 0,603 & Valid \\
\hline & & $\mathrm{X} 1.4$ & 0,697 & Valid \\
\hline & & $\mathrm{X} 1.5$ & 0,869 & Valid \\
\hline \multirow[t]{6}{*}{ Motivasi Belajar $\left(\mathrm{X}_{2}\right)$} & \multirow[t]{6}{*}{0,745} & $\mathrm{X} 2.1$ & 0,491 & Valid \\
\hline & & $\mathrm{X} 2.2$ & 0,856 & Valid \\
\hline & & $\mathrm{X} 2.3$ & 0,722 & Valid \\
\hline & & $\mathrm{X} 2.4$ & 0,826 & Valid \\
\hline & & $\mathrm{X} 2.5$ & 0,732 & Valid \\
\hline & & $\mathrm{X} 2.6$ & 0,803 & Valid \\
\hline \multirow[t]{6}{*}{ Kepuasan (Y) } & \multirow[t]{6}{*}{0,652} & Y1 & 0,658 & Valid \\
\hline & & Y2 & 0,825 & Valid \\
\hline & & Y3 & 0,821 & Valid \\
\hline & & Y4 & 0,605 & Valid \\
\hline & & Y5 & 0,802 & Valid \\
\hline & & Y6 & 0,449 & Valid \\
\hline
\end{tabular}

Sumber : Pengolahan data SPSS 19.0, 2020

\section{Uji Reliabilitas}

Untuk mengetahui reliabilitas dalam riset ini maka nilai cronbach alpha > 0,7 maka variabel tersebut dikatakan reliabel. Dalam riset ini nilai cronbach alpha dari setiap variabel adalah sebagai berikut: penggunaan media daring $\left(\mathrm{X}_{1}\right)$ nilai cronbach alpha sebesar 0,811 maka variabel ini dikatakan reliabel, variabel motivasi belajar $\left(\mathrm{X}_{2}\right)$ cronbach alpha memiliki nilai sebesar 0,821 maka variabel ini dikatakan valid dan variabel kepuasan (Y) cronbach alpha memiliki nilai sebesar 0,765 maka dikatakan valid.

Maka dalam riset ini keseluruhan varibel memiliki nilai cronbach alpha lebih dari 0,7 dan dinyatakan reliabel.

\section{Analisis Regresi Berganda}

Berdasarkan tabel 2 dapat dijelaskan bahwa hasil persamaan dalam riset ini adalah :

$$
\mathrm{Y} 1=0,543 \mathrm{X} 1+0,189 \mathrm{X} 2
$$

Hasil persamaan diatas mengukuhkan bahwa variabel penggunaan media daring dan motivasi belajar memiliki nilai positif, artinya bahwa semakin baik pemilihan penggunaan media daring dan motivasi belajar maka mahasiswa akan merasa puas. Hasil riset ini menunjukan penggunaan media daring dalam proses kuliah daring mempengaruhi kepuasan mahasiswa sebanyak 54,3\% sedangkan motivasi belajar mahasiswa selama kuliah daring mempengaruhi kepuasan mahasiswa sebanyak $18,9 \%$. 
Tabel 2 Analisis Regresi Berganda

\begin{tabular}{|l|c|c|c|l|}
\hline \multicolumn{1}{|c|}{ Model } & \multirow{2}{*}{$\begin{array}{c}\text { Adjusted R } \\
\text { Square }\end{array}$} & \multicolumn{2}{|c|}{ Uji t } & Keterangan \\
\cline { 3 - 5 } & & Stand. Coef & Sig. & \\
\hline $\begin{array}{l}\text { Penggunaan Media Daring } \\
\text { Terhadap Kepuasan }\end{array}$ & 0,448 & 0,543 & 0,000 & Diterima \\
\cline { 1 - 1 } $\begin{array}{l}\text { Motivasi Belajar Terhadap } \\
\text { Kepuasan }\end{array}$ & & 0,189 & 0,028 & Diterima \\
\cline { 3 - 5 } & & & & \\
\hline
\end{tabular}

Sumber: Pengolahan data SPSS 19.0, 2020

\section{KESIMPULAN}

Penyebaran Covid-19 yang semakin meningkat sejak awal tahun 2020 berdampak pada semua sektor salah satunya adalah pendidikan, dimana proses belajar mengajar selama ini menggunakan media tatap muka tetapi dengan adanya pandemi ini merubah sistem pembelajarannya melalui media dalam jaringan (daring). Program Studi Teknologi Informatika ITS NU Pekalongan dan Program Studi Administrasi Perkantoran Politeknik Pusmanu telah menerapkan sistem kuliah online sejak awal semester genap 2019/2020. Berdasarkan hasil riset yang dilakukan menunjukan bahwa penggunaan media daring mempunyai pengaruh terhadap kepuasan mahasiswa, dimana mahasiswa dalam prosese kuliah online sudah paham mengenai instruksi belajar dalam penggunaan media pembelajaran tersebut dan selalu menyelesaikan tugas yang disampaikan oleh dosen dengan waktu yang telah disepakati bersama. Akan tetapi, tingkat perhatian mahasiswa dalam proses kuliah online khususnya saat pemaparan materi oleh dosen masih tergolong minim. Mahasiswa merasa puas jika dalam pelaksanaan kuliah online tidak ada kendala dengan jaringan internet dan kuota internet. Mahasiswa memilih google classroom sebagai media pembelajaran yang paling disukai. Hal ini menjadi masukan dalam memilih media pembelajaran untuk perkuliahan online.

\section{REFERENSI}

Fitriyani, Y., Fauzi, I., \& Sari, M. Z. (2020). Motivasi Belajar Mahasiswa Pada Pembelajaran Daring Selama Pandemik Covid-19. Jurnal Kependidikan: Jurnal Hasil Penelitian Dan Kajian Kepustakaan Di Bidang Pendidikan, Pengajaran Dan Pembelajaran. https://doi.org/10.33394/jk.v6i2.2654
Hanum, N. S. (2013). Keefetifan e-learning sebagai media pembelajaran (studi evaluasi model pembelajaran e-learning SMK Telkom Sandhy Putra Purwokerto). Jurnal Pendidikan Vokasi. https://doi.org/10.21831/jpv.v3i1.1584

Mujibul, M., \& Hakim, R. F. (2019). Analisis Kinerja Karyawan Studi Kasus PT. Reycom Dokumen Solusi. Jurnal Dinamika Ekonomi Dan Bisnis, 16(1), 1-16. https://doi.org/https://doi.org/10.34001/jdeb.v1 6 i1. 953

Mulyaningsih, I. E. (2014). Pengaruh Interaksi Sosial Keluarga, Motivasi Belajar, dan Kemandirian Belajar terhadap Prestasi Belajar. Jurnal Pendidikan Dan Kebudayaan. https://doi.org/10.24832/jpnk.v20i4.156

Mulyapradana, A. (2017). Upaya Peningkatan Kepuasan Masyarakat Terhadap Pelayanan Pada Kantor Kecamatan Pekalongan Timur. Widya Cipta - Jurnal Sekretari Dan Manajemen.

Mulyapradana, A., Anjarini, A. D., \& Harnoto, H. (2020). Pengaruh Kualitas Pelayanan Terhadap Kepuasan Pelanggan di PT. Tempo Cabang Tegal. Jesya (Jurnal Ekonomi \& Ekonomi Syariah). https://doi.org/10.36778/jesya.v3i1.115

Naserly, M. K. (2020). Implementasi Zoom, Google Classroom, Dan Whatsapp Group Dalam Mendukung Pembelajaran Daring (Online) Pada Mata Kuliah Bahasa Inggris Lanjut. Jurnal Aksara Public, 4(2), 155-165. https://aksarapublic.com/index.php/home/artic le/view/417

Pujadi, A. (2007). Faktor-Faktor Yang Mempengaruhi Motivasi Belajar Mahasiswa: Studi Kasus Pada Fakultas Ekonomi Universitas Bunda Mulia. Business Management Journal, 3(2), 40-51. https://doi.org/10.30813/bmj.v3i2.338

Romadon, R., \& Maryam, E. (2019). Pengaruh Penggunaan Medi Pembelajaran Lampu Otomatis Terhadap Hasil dan Motivasi Belajar 
Mahasiswa Pada Mata Kuliah Fisika Listrik. SILAMPARI JURNAL PENDIDIKAN ILMU FISIKA.

https://doi.org/10.31540/sjpif.v1i2.797

Setiawan, S., \& Mulyapradana, A. (2018). Peran Work Motivation Sebagai Variabel Intervening Pengaruh Reward Instrinsik, Supervision Of Work \& Satisfacation Of Compensation Terhadap Employee Performance. Jesya (Jurnal Ekonomi \& Ekonomi Syariah). https://doi.org/10.36778/jesya.v2i1.26

Setiyani, R. (2010). Pemanfaatan Internet Sebagai Sumber Belajar. Dinamika Pendidikan, V(2), 117-133.

https://doi.org/10.15294/dp.v5i2.4921
Suni Astini, N. K. (2020). Tantangan Dan Peluang Pemanfaatan Teknologi Informasi Dalam Pembelajaran Online Masa Covid-19. Cetta: Jurnal Ilmu Pendidikan. https://doi.org/10.37329/cetta.v3i2.452

Winangun, I. M. A. (2020). Penerapan Model Discovery Learning Berbasis Digital untuk Meningkatkan Motivasi dan Hasil Belajar Mahasiswa pada Mata Kuliah Media Pembelajaran SD. Jurnal Mitra Pendidikan. 